\title{
Analysis of Carrying Capacity of the Porong River Caused by Sidoarjo Mud Disposal
}

\author{
Robert Agung Abdi Saputro ${ }^{1 *}$, Suhardjono ${ }^{1}$, Pitojo Tri Juwono ${ }^{1}$ \\ ${ }^{1}$ Water Resources Engineering Department, Universitas Brawijaya, Malang, 65145, Indonesia \\ *r.agungwre01@gmail.com
}

Received 20-01-2021; accepted 23-08-2021

\begin{abstract}
This study aims to examine the sediment distribution models and the stream sediment distribution due to mud disposal of Porong River. It examines how the sediment distribution models and deposition, the distribution of stream sediment due to mud disposal along with its impacts on the river's capacity, and whether the mud disposal has a harmful impact on the water quality. The data used were based on topographic and Bathymetric data of Porong River, crosssections of the river, and terrain sediment distribution patterns. The study conducted field and secondary data analysis, hydrological analysis, oceanographic analysis of Mura River and river hydraulic analysis. The study concludes that to maintain its capacity and prevent negative impacts, it is necessary to protect the cliffs and embankments along the segment of the river. To protect the community pond area, overburden and/or river dredging activities along with the segments from the branch to the estuary of the river are needed. Furthermore, it is also necessary to add artificial inputs such as submersible Kribs that are arranged on piles to deal with problems of river sediments in the mouth of Porong River.
\end{abstract}

Keywords: Porong River, Sedimentation, Sidoarjo Mud

\section{Introduction}

The mudflow in Porong, Sidoarjo, which occurred on May 29, 2006, continues to this day. The state of mudflow still shows fluctuation in large, medium and small range, reaching 1 to 3 meters in height. It is estimated that the mudsflow will last about 20-30 years, while the possibility of closing the flow of success is very low.

In accordance with Perpres (Presidential Decree) 14/2007 jo. Perpres 48/2008 jo. Perpres 40/2009, the mud overflow is to be dumped into the sea via Porong River. Porong Riverwas chosen because beside of being ready for use for the ongoing disaster, it is also in the long term that has the most economical operating and maintenance costs for the energy station [1]. The management of the disposal of the mudsflow from the mud storage basin to Porong River is carried out optimally during the rainy season, while during the dry season it is carried out in a limited way. This role should be maintained and

Cite this as: Saputro, R.A.A., Suhardjono, S. \& Juwono, P.T. (2021). Analysis of Carrying Capacity of the Porong River Caused by Sidoarjo Mud Disposal. Civil and Environmental Science Journal (Civense), 4(2), 192201. doi: https://doi.org/10.21776/ub.civense.2021.00402.9 
secured so that the additional mudflow does not reduce the capacity of the Porong River and does not cause flooding upstream and / or indirectly in the influence are of Porong River.

The disposal of the mud in the Porong River is not the target of the final elimination but only as a means of draining the mud into the sea. For the mud to flow into the sea and at the same time to maintain the Porong River's performance in flood control in the Brantas River, it is necessary to carry out activities to safeguard the Porong River.

With over 11 (eleven) years of experience in using Porong River as a means of channeling mud into the sea, it is hoped that in the coming years things will not happen to harm or reduce the function of Porong River as a diversion channel for the Brantas watershed. In addition, a study found that a significant sediment deposition occurred at the river bed of Porong River due to increase sediment discharge from the volcano during dry periods [2].

Furthermore, in accordance with Presidential Decree No. 40 of 2009 of the Republic of Indonesia, in Article 9 point d [3], Porong River's functions are added to deal with the overflow of mud of Sidoarjo so that the mud can flow into the sea and at the same time maintain the performance of the Porong River in flood control in the Brantas River watershed (Figure 1). With the addition of these functions, it is necessary to conduct a capacity analysis for Porong River. Thus, this study tries to examine the sediment distribution models, and the stream sediment distribution due to mud disposal.

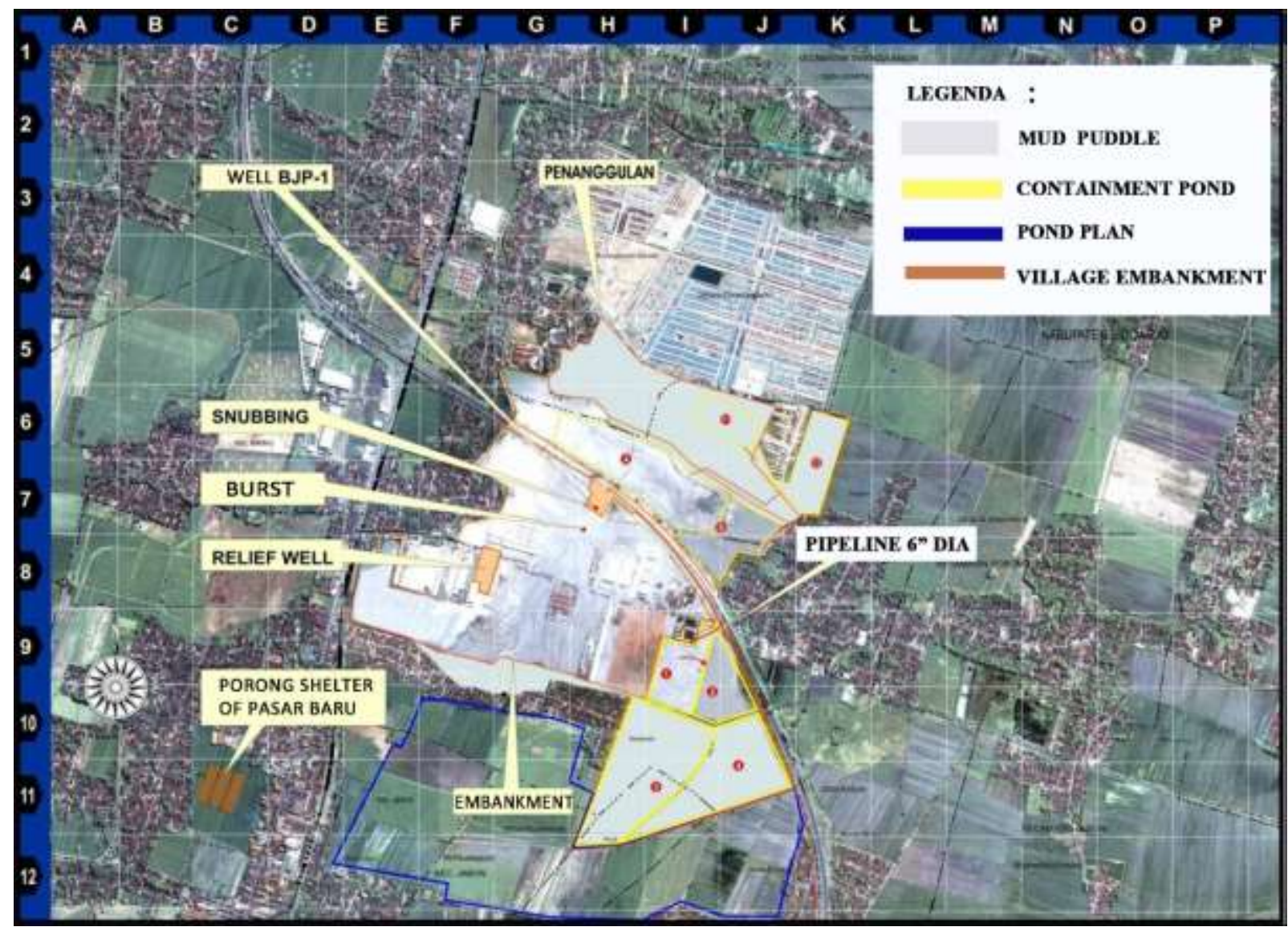

Figure 1. Profile of Outlet Stretch of the Porong River Mud

\section{Material and Method}

\subsection{Data}

This study used the analysis of Porong River topographic data and Bathimetry, river cross section and field sediment distribution models [3] [4]. Meanwhile, to get the type of tides of Porong River 
estuary, this study analyzed tidal observation data and BMKG (Meterological, Climatological, and Geophysical Agency) or other secondary data. In hydrological analysis, the data used are AWLR flow data.

The secondary data of this study include the oceanographic data of wind direction and speed, as well as characteristics and mud flows that have been in the laboratory. In addition, the discharge recording of the discharge of sludge discharged into the Porong River is also carried out with a sludge content ratio: $20 \%$ solids, $80 \%$ water.

\subsection{Steps in the Research Process}

The analysis process of this study is grouped into four, including field and secondary data analysis, hydrological analysis, oceanographic analysis of Porong River estuary, and hydrological analysis of Porong River.

a. Field and secondary data analysis includes topographic data and Bathymetry analysis of the Porong River cross section and changes in the capacity volume of the Porong River, and the terrain sediment distribution model. The other data are in the form of data of the sediment characteristics of the Porong River, tidal observations and BMKG secondary data, as well as the water quality of Porong River due to the Sidoarjo mudflow and its impact on the environment;

b. The hydrological analysis carried out is in the form of a flood opportunity analysis that crosses the Porong River by verifying the AWLR data;

c. Oceanographic analysis of Porong River estuary includes analysis of wind direction and speed data to obtain wind rose and the analysis of Porong River sedimentation and erosion models along the coastline;

d. In the analysis of river hydraulics, the study conducted an analysis of the water level profile of the Porong River flood before the outlet, the outlet at the mouth of the Kali River, as well as the analysis of the distribution of river sedimentation due to mud disposal.

\section{Results and Discussion}

\subsection{Sediment Distribution Patterns}

a. Assessment on the Distribution of Existing Sediment Transport in the Field

In this analysis, the topography and Bathymetry of the Porong River were carried out starting from the upstream of the Sidoarjo Mud Outlet pipe to the mouth of the Porong River. Previously, a study shows that the period of movement patterns of water upstream from the offshore direction towards the plug (ups) and the movement would leave for offshore direction towards the downs [5]. Bathymetry measurements were also carried out offshore jutting into the sea on the left and right of the Kali Porong estuary as well as the front area of Lusi Island (Figure 2). Additionally, Lusi Island is not only receiving mud sourced from Sidoarjo mud, but also from three watershed systems (Figure 3).

The study of the distribution of sediment transport in the existing conditions is the result of the identification of the deposition area and the scour area. Sources of data used are the results of the 2014 Porong River Bathimetry and Topographic and Bathymetry measurement data in this work.

Based on Bathimetry and Topographic data for the 2014 and 2019 measurement, the difference is calculated using the Raster Method. Raster Calculator calculation results for the volume of precipitation:

The difference between 2019 and 2014 elevation times the Cell Size Raster is as follows:

Sediment Volume : 2.490.766,25 $\mathrm{m}^{3}$;

Scour Volume $\quad: 3.228 .751,50 \mathrm{~m}^{3}$.

\section{Sediment Distribution Model in 2014 Bathymetry}

Lusi Island was formed at the Porong River estuary in 2014. The previous formation of Lusi Island was a soil bank area resulting from the Dragging of Porong River. Some study shows that it's the concentration of heavy metals contained in its mud were below environmental soil quality guidelines [6]. Similar founding occurred at Porong River Estuary [7]. In 2014, the Lusi Island had not yet formed 
new mangroves and islands as in the current state of 2019. Additionaly, in 2012, the mangroves growth in the mouth of Porong River is found to create an increase of areas in the wetland of more than 10 ha [8].

This study aims to examine the models of sediment distribution and deposition. Therefore, this study looks into the field conditions in 2014 modeled with the prediction result and the current condition in 2019. Here is a picture of the sedimentation distribution model in 2014:

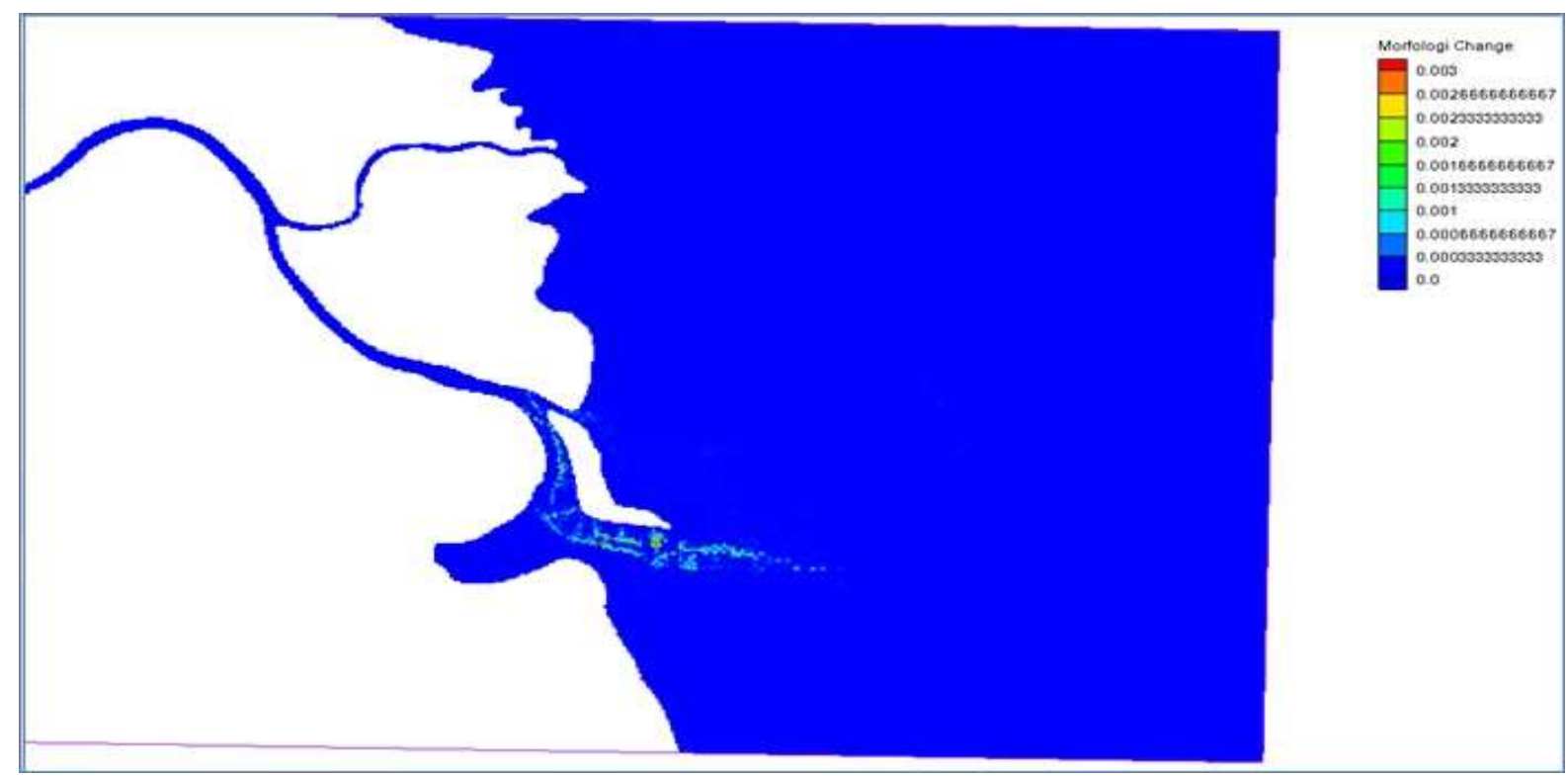

Figure 2. Sediment distribution model at the Porong River estuary and Lusi Island; sediment sourced from Sidoarjo mud.

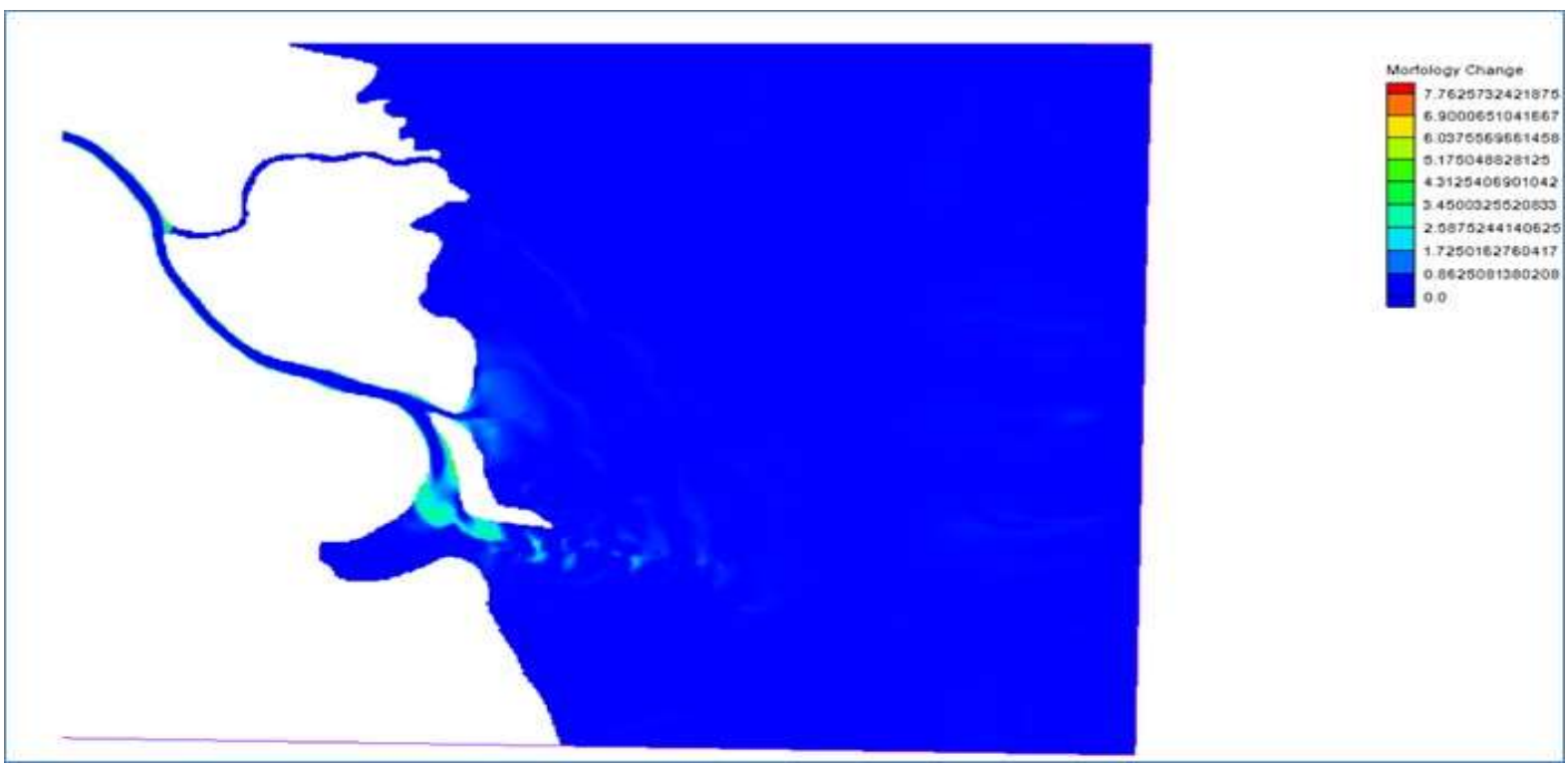

Figure 3. Sediment distribution model at Porong River estuary and Lusi Island; sediment sourced from Sidoarjo mud and 3 watershed (DAS) systems. 


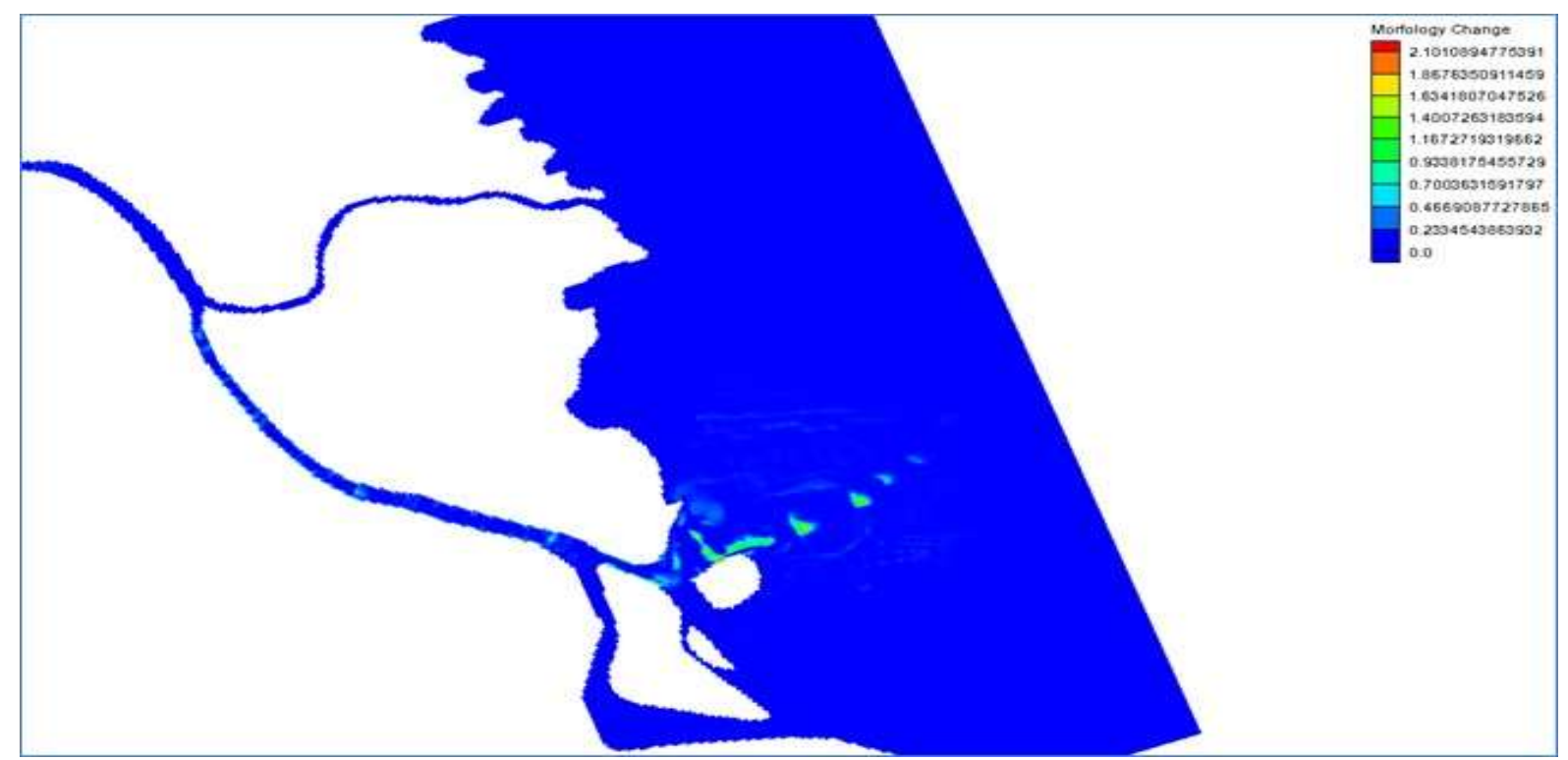

Figure 4. Sediment distribution model in 2019 Bathymetry during dry season

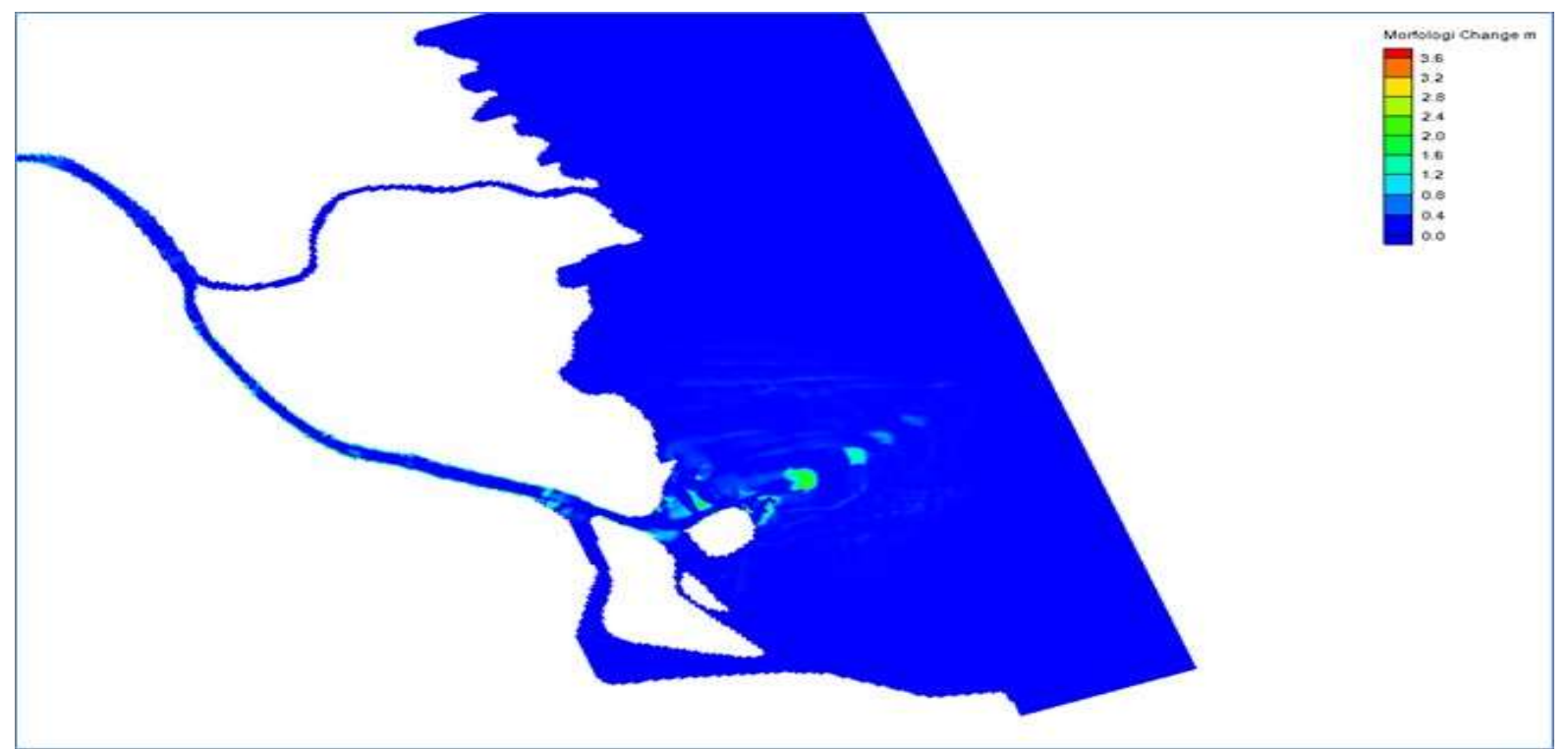

Figure 5. Sediment distribution model in 2019 Bathymetry during wet season

\section{Sediment Distribution Model in 2019 Bathymetry}

The aim of the 2019 bathymetric data modeling analysis is to predict future distribution patterns so that the required estuary repair planning can be done [9]. From the bathymetric modeling in 2019, it can be concluded that there will be an accumulation of sediment deposits at the mouth of the Porong River estuary between Baru Island and Lusi Island. The sediment distribution appears to be different in every season. In Figure 4, it can be seen the sediment distribution during dry season. Meanwhile, Figure 5 shows a different pattern of the distribution during wet season and the wider model is spotted during flood season (Figure 6). Furthermore, a study found that during wet season, the thickness of the sediment in Lusi Island is ranged from 1.6 to $2.6 \mathrm{~m}$ [10]: 


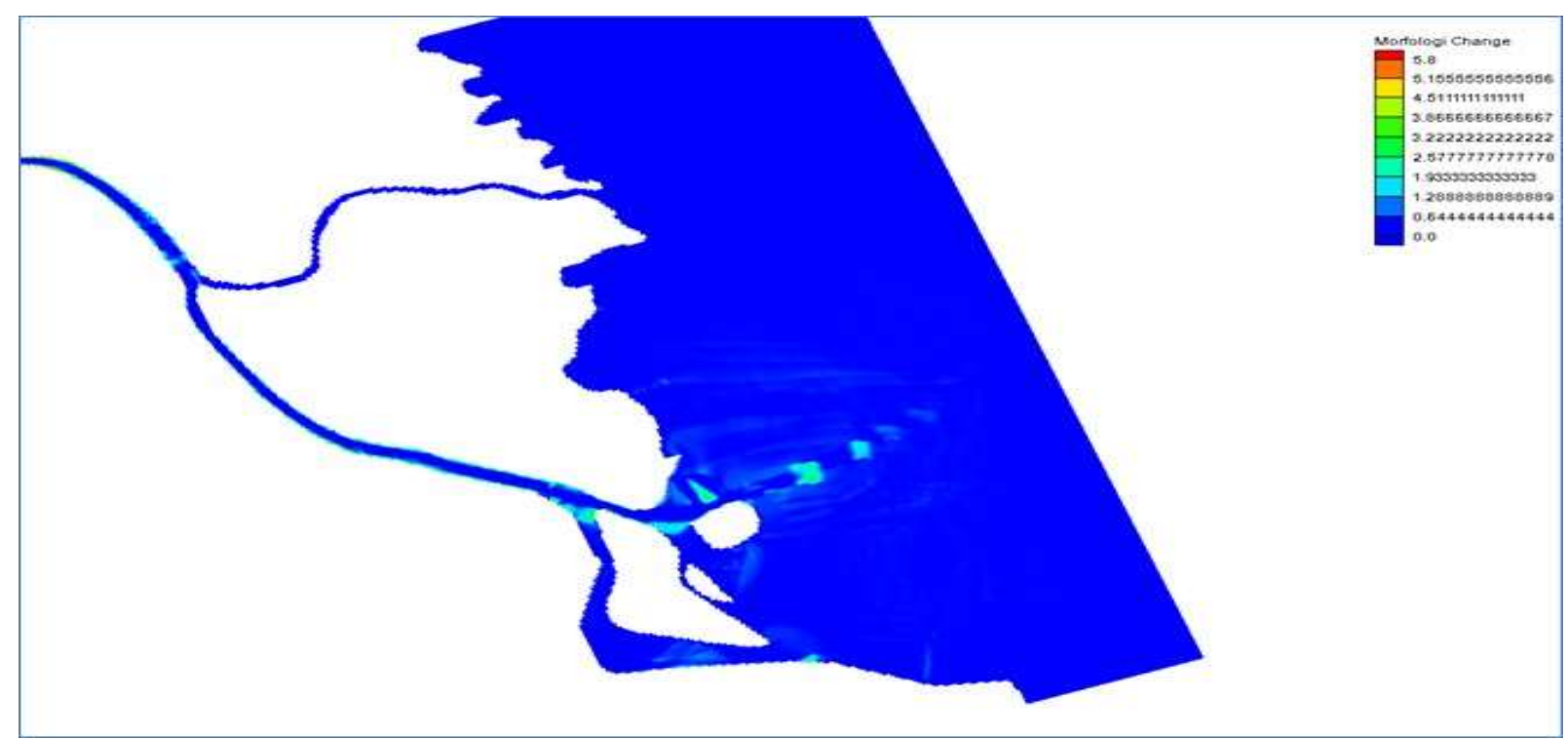

Figure 6. Sediment distribution model in 2019 Bathymetry during flood season

\section{a. Inflow Sediment of Porong River}

A modeling has been tested to represent field conditions, so that the value of the sediment concentration in the time series approach that occurred during 2009 to 2018 can be used using AVSWAT modeling data [1]. The sediment inflow in Porong River is the cumulative amount of sediment in the two watershed outlets, namely Kali Sadar and Kali Kambing is presented in Figure 7.

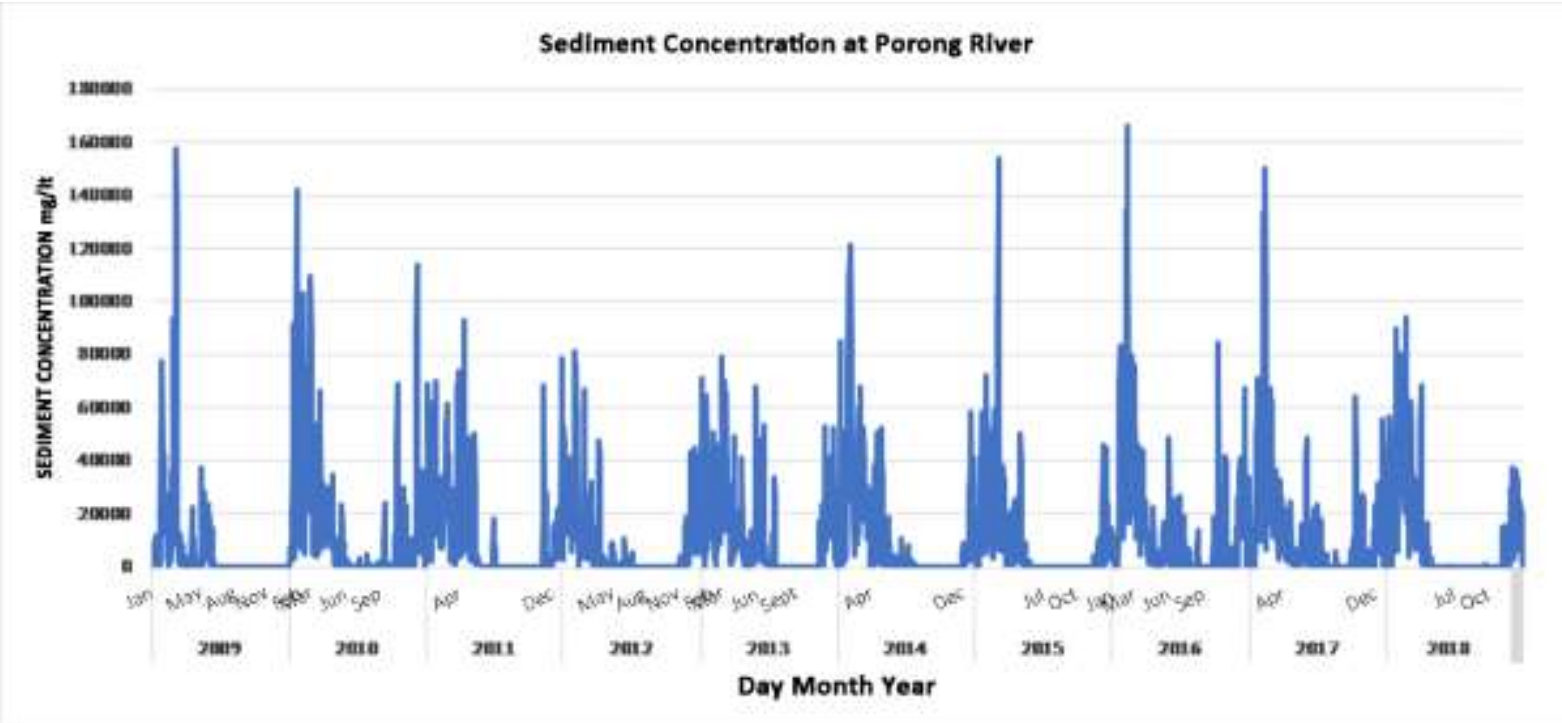

Figure 7 . Sediment Concentration Time Series Result of AVSWAT Model 2000

\subsection{Assessment of River Sediment Distribution due to Mud Disposal}

a. Assessment of Sediment Distribution of Normal / Existing Operation Pattern

In the model test of the conditions of the normal discharge flow limit, the 3 sediment watershed systems (Sadar River Watershed, Kambing River Watershed, Outflow Weir Lengkong and the disposal of Sidoarjo Mud as in the existing operating pattern are currently operating resulting in changes in the base in the river fork of Porong River around $0.065 \mathrm{~m}$ annually [11]. 
At the mouth of the Porong River, located near Lusi Island, the change in sediment deposits is 0.064 $\mathrm{m}$ each year. In the Sidoarjo Mud outlet location area up to $1 \mathrm{~km}$ downstream is $0.073 \mathrm{~m}$ to $0.07 \mathrm{~m}$.

If this modeling is compared/verified according to the results of field measurements in 2014 and 2019 , the sedimentation rate at the Porong Rivers branch is $1.03 \mathrm{~m} / 5$ years or $0.21 \mathrm{~m}$ each year [3] [4] (Figure 8).

Whereas the field verification for the Kali Porong estuary area near Lusi Island is $3.9 \mathrm{~m} / 5$ years or 0.78 per year, while the modeling results produce $0.064 \mathrm{~m}$ each year, so there is a difference of $0.716 \mathrm{~m}$ which is assumed to be due to the flow effect of the pattern, tides, and the coastal sediment.

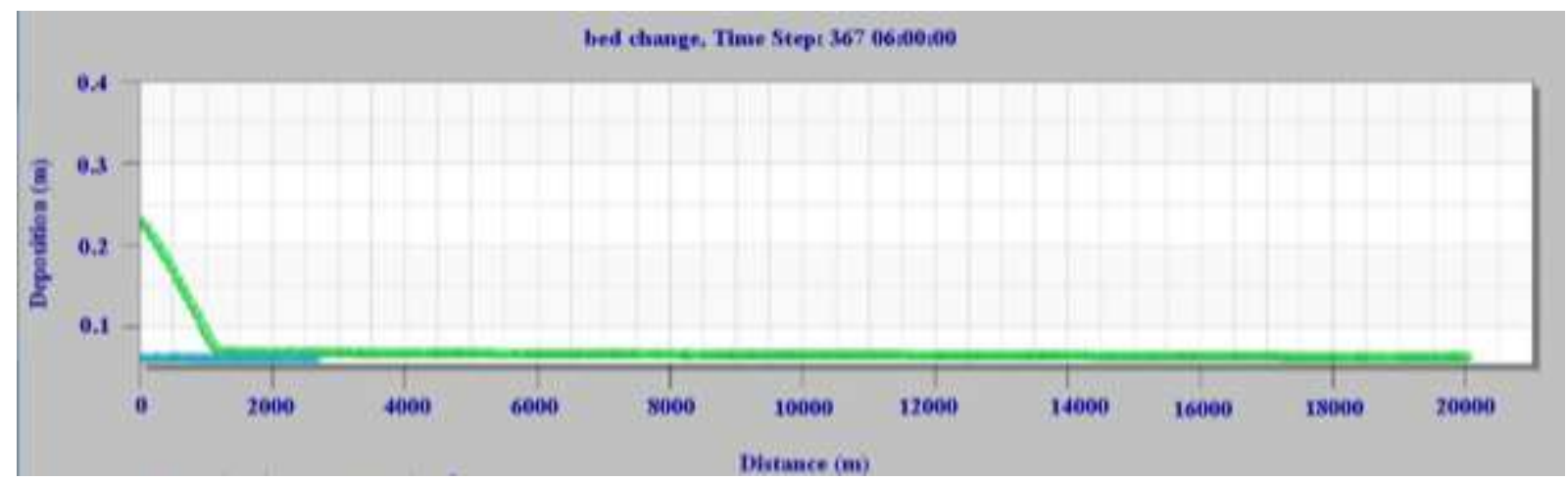

Figure 8. Profile of Sediment in Porong River resulting from watershed sediment and existing operation model of Sidoarjo Mud.

\section{b. Assessment of Sediment Distribution for Operation Pattern Increased $2 x$}

The operation pattern of Sidoarjo mud disposal is increased to $2 \mathrm{x}$ normal operations, resulting in an increase in sediment deposits in the estuary to changes in the base in the river fork for Porong River 0.14 m annually.

The impact of deposition in the Watershed of Lusi Island is $0.132 \mathrm{~m}$ annually. The pattern of increased sediment deposition due to surgery is increased to 2 times (Figure 9).

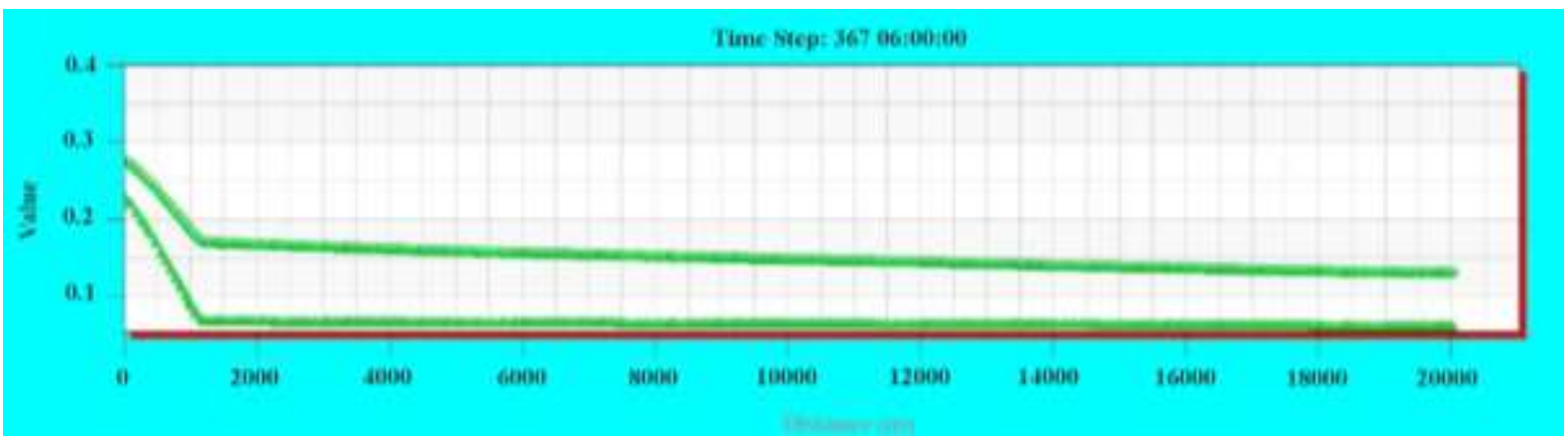

Figure 9. Profile of Sediment of Porong River up to the estuary due to the impact of the watershed sediment and the existing operation pattern of Sidoarjo Mud and increased 2 times.

\section{c. Assessment of Sediment Distribution for Operation Pattern Increased $5 x$}

The addition of the discharge capacity of Sidoarjo Mud to Porong River via the outlet pipe was increased by 5 times, which results a $0.1 \mathrm{~m}$ increase in sedimentation rate each year from the existing discharge. Additional capacity can be seen in the area of the outlet nozzle, increasing by $0.38 \mathrm{~m}$ (Figure 10) each year. 


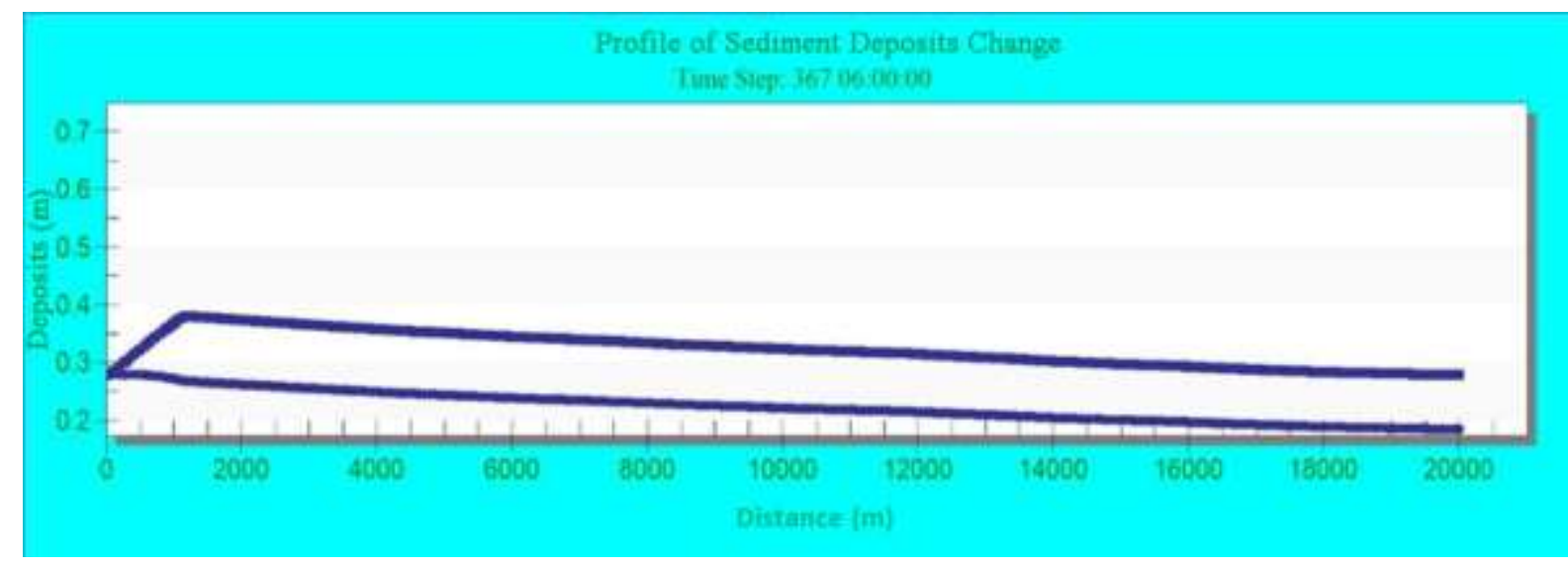

Figure 10. The sediment profile in Porong River to the estuary caused by watershed sediment and the existing operation pattern of Sidoarjo Mud and increased 5 times.

\section{d. Assessment of Sediment Distribution for Operation Pattern Increased 10x}

As a result of the operation pattern increased to $10 \mathrm{x}$ from the current operation, it takes the need for the operation pattern of Porong River $4 \mathrm{Km}$ from the Outlet for every 5 years monitoring until dredging, so in this study it is not recommended to apply this operating pattern. As the operation is increased to $10 \mathrm{x}$, there is also an increase of the sediment deposits as seen in Figure 11.

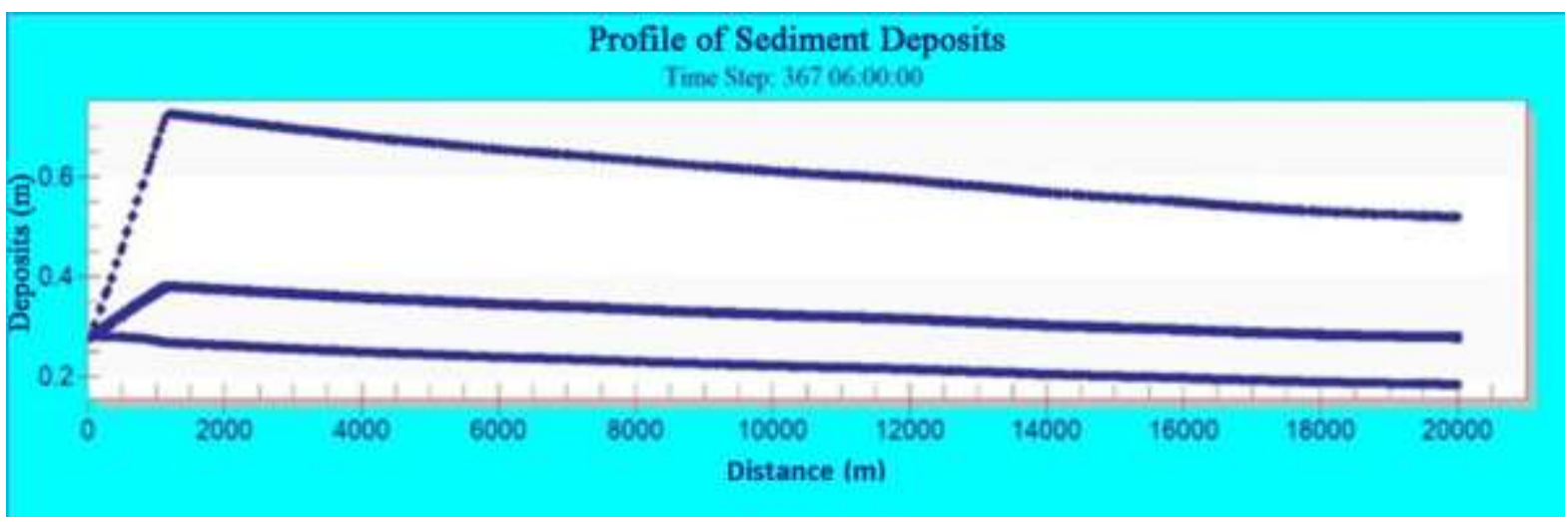

Figure 11. The sediment profile in Porong River to the estuary caused by watershed sediment and the existing operation pattern of Sidoarjo Mud and increased 10 times.

\subsection{The Analysis of Environmental Impact}

According to the result of water quality testing and field monitoring, it can be concluded as follows:

1. The water quality standards are classified in class 3 , are always safe for the water supply of ponds and do not cause pollution that could endanger the fishing ecosystem [12]. Additionally, in a study conducted by Triaji et.al (2017), the water quality of Porong River is classified as Medium criteria through an analysis using NSF-WQI (National Sanitation Foundation - Water Quality Index) [13]. Furthermore, the parameters show the quality of the water is worth of $34, \mathrm{~g} / \mathrm{L}$ for COD, $14.46 \mathrm{mg} / \mathrm{L}$ for nitrate, $30 \mathrm{mg} / \mathrm{L}$ for TTS, and $0.43 \mathrm{mg} / \mathrm{L}$ for phosphrate [14]. In terms of the founding of TTS, similar condition is found in Brantas river [15] without being polluted based on the TDS parameter [16-17].

2. Further downstream from Porong River, the tidal effect is increasingly visible, where the brackish water category is visible at a distance of $750 \mathrm{~m}$ from the Sidoarjo Mud outlet. 
3. Porong River waters after discharge may contain high mineral and metal content mixed with salinity levels already in brackish water category;

4. The lower the conditions of the DO parameter, the higher the indication of the reduction process in water;

5. It is possible that the effect of the discharge from Sidoarjo Mud has a direct effect on the increase of the TDS parameter in the waters of Porong River.

\section{Conclusions}

Based on the calculation using Raster method, it shows that there has been a difference between the Bathymetric and topographic data in 2014 and 2019 in terms of the sediment and the scour of the Porong River. The difference of the sediment is $2.490 .766,25 \mathrm{~m}^{3}$, while the scour of the river is $3.228 .751,50$ $\mathrm{m}^{3}$. This difference shows that the capacity the Porong River has in 2014 is bigger than in 2019. The decreasing capacity of the river each year results in increasing in the elimination capacity of Sidoarjo Mud can be allowed to 5 times the current capacity. Thus, in order to maintain the capacity of Porong River, proper planning is required so as not to have negative impacts on the environment.

\section{References}

[1] E. Suhartanto, Panduan AVSWAT 2000 dan Aplikasinya di Bidang Teknik Sumber Daya Air. 2008

[2] S. Kure, B. Winarta, Y. Takaeda, K. Udo, "Effects of Mud Flows from the LUSI Mud Volcano on the Porong River Estuary, Indonesia," Journal of Coastal Research. Coastal Education and Research Foundation, vol. 70 no. 70, pp. 568-573, Apr, 2014

[3] Peraturan Presiden Republik Indonesai Nomor 40, 2009, Badan Penanggulangan Lumpur Sidoarjo, Jakarta.

[4] D. Priyantoro, Teknik Pengangkutan Sedimen. 1987

[5] M. Mustain, "The Model of Current Pattern at the Mouth of Porong River Sidoarjo," International Journal of Civil Engineering and Technology (IJCIET), vol. 9, no. 1, pp. 688701, Jan, 2018

[6] B. D. Krisnayanti, D. S. Agustawijaya, "Characteristics of Lusi Mud Volcano and Its Impact on The Porong River," Journal of Degraded and Mining Lands Management, vol. 1, no. 4, pp. 207-210, July, 2014

[7] L. K. Harlyan, R. Dwi, S. H. J. Sari, F. Iranawati, "Concentration of Heavy Metal (Pb and Cu) in Sediment and Mangrove Avicennia Marina at Porong River Estuary, Sidoarjo, East Java," Research Journal of Life Science, vol. 2, no. 2, pp. 124-132, Aug. 2015

[8] F. Sidik, T. Hidayatullah, H. P. Kadarisman, C. E. Lovelock, "Evaluation of Mangrove Development in A Created Mangrove Wetland in Porong, East Java," Regional Symposium on Mangrove Ecosyste Management in Southeast Asia. Eds. Bedjo Santoso and Takahisa Kusano. Ministry of Forestry - Indonesia Proc., March, 2013

[9] B. W. Parkinson, Global Positioning System : Theory and Applications, Volume II. 1996

[10] A. K. Engki , P. Dj. Viv, "Tidal, Wave, Current, and Sediment Flow Patterns in Wet Season in the Estuary of Porong River Sidoarjo, Indonesia," ISOCEEN 2017. Matec Web Conference. vol. 177, pp. 1-13, July. 2018

[11] G. W. Breusers, "River Analysis System HEC-RAS." Hydraulic Reference Manual Version 4.1. California., 2012

[12] Peraturan Pemerintah Republik Indonesia Nomor 82, 2001. Pengelolaan Kualitas Air dan Pengendalian Pencemaran Air. Jakarta.

[13] M. Triaji, R. Yenny, M. Mahmudi, "Analysis of Water Quality Status in Porong River," Jurnal Pembangunan dan Alam Lestari, vol. 8, no. 2, 2017

[14] I. Suntoyo, Z. Hasan, S. Muhammad, N. Sukmasari, G. Angraeni, H. Tanaha, M. Umeda. S. Kure, "Modelling of the COD, TTS, Phosphate and Nitrate Distribution Due to the Sidoarjo Mud 
Flow into Porong River Estuary," Procedia Earth and Planetary Science, vol. 14, doi.10.1016/j.proeps.2015.07.095, Jul, 2015

[15] G. Verstraeten, Ian P. Prosser, P. Fogarty, Predicting the Spatial Patterns of Hillslope Sediment Delivery to River Channels in the Murrumbidgee Catchment, Journal of Hydrology. 2007

[16] Kustamar, L. K. Wulandari, "The Pollution Index ad Carrying Capacity of the Upstream Brantas River," International Journal of GEOMATE, vol. 9, no. 73, pp. 26-32, March, 2020.

[17] Haribowo, R., Dermawan, V., \& Yudha, N. (2018). Application of Artificial Neural Network for Defining the Water Quality in The River. Civil and Environmental Science Journal (CIVENSE), 1(1), pp.12-18. doi:https://doi.org/10.21776/ub.civense.2018.00101.2. 